Original Article

\title{
Toxicity of Nicotine by Repeated Intratracheal Instillation to F344 Rats
}

\author{
Masanao Yokohira ${ }^{1}$, Yuko Nakano${ }^{1}$, Nozomi Hashimoto $^{1}$, Keiko Yamakawa $^{1}$, \\ Fumiko Ninomiya ${ }^{1}$, Sosuke Kishi ${ }^{1}$, Kousuke Saoo ${ }^{1,2}$, and Katsumi Imaida ${ }^{1 *}$ \\ ${ }^{1}$ Onco-Pathology, Department of Pathology and Host-Defense, Kagawa University, Kagawa 761-0793, Japan \\ ${ }^{2}$ Diagnostic Pathology, Kaisei General Hospital, Kagawa 762-0007, Japan
}

\begin{abstract}
In vivo, nicotine in cigarette smoke induces various effects not only on the respiratory system but also the central and peripheral nerve systems, circulatory organs and digestive organs, and there is a possibility of promotion of lung tumorigenesis. The present experiment was conducted to examine histopathological changes caused by nicotine in the lung with repeated intratracheal instillation (i.t.). Six-week-old male F344 rats were administered nicotine by i.t. at doses of 0.05, 0.1 and $0.2 \mathrm{mg}$ nicotine/rat every 3 weeks beginning at week 4 , for up to a total of 9 times and were then sacrificed at week 30 . The total number of administrations, total dose of nicotine and effective number of rats were 9 times, $0.45 \mathrm{mg}$ and 5 rats and 4 times, $0.20 \mathrm{mg}$ and 5 rats for the $0.05 \mathrm{mg}$ nicotine $/ \mathrm{rat}$ group; 3 times, $0.30 \mathrm{mg}$ and 5 rats and 4 times, $0.40 \mathrm{mg}$ and 3 rats for the $0.1 \mathrm{mg}$ group; and 3 times, $0.60 \mathrm{mg}$ and $3 \mathrm{rats}$ for the $0.2 \mathrm{mg}$ group, respectively. As a control group, 5 rats were administered $0.2 \mathrm{ml}$ saline/rat 9 times. Some rats administered $0.1 \mathrm{and} 0.2 \mathrm{mg}$ nicotine suffered convulsions just after administration. Histopathologically, though proliferative changes were not observed, neutrophil infiltration, edema and fibrosis in the lung were induced by nicotine. In conclusion, repeated treatment of nicotine promoted neurologic symptoms in the acute phase, and strong inflammation in the lungs in the chronic phase, even at a low dose. Toxicity of nicotine is suggested to depend not on total dose of nicotine in the experiment but rather on repeated injury with consecutive administration. (DOI: 10.1293/tox.25.257; J Toxicol Pathol 2012; 25: 257-263)
\end{abstract}

Key words: nicotine, lung, intratracheal instillation, toxicity, rat

\section{Introduction}

There are many chemicals including carcinogens in cigarette smoke, and at least 4000 component compounds have been described ${ }^{1}$. Of the smoking-related chemicals, nicotine is one of the major important components with toxicity. Nicotine is taken into the blood via the lungs from the inhaled smoke and binds to nicotinic acetylcholine receptors on the central and peripheral nerves ${ }^{2}$. It thereby induces various effects not only in the respiratory system but also circulatory and digestive organs ${ }^{3-5}$. In addition, according to a previous report, nicotine enhances proliferation, migration, and radioresistance of human malignant glioma cells through EGFR activation ${ }^{6}$. Nicotine is the addictive component of tobacco acting on neuronal nicotinic receptors (nAChRs). Functional nAChRs are also present on endothelial, hematological and epithelial cells ${ }^{7}$. Nicotine has been

Received: 8 August 2012, Accepted: 19 September 2012

*Corresponding author: K Imaida (e-mail: imaida@med.kagawa-u. ac.jp)

(C)2012 The Japanese Society of Toxicologic Pathology

This is an open-access article distributed under the terms of the Creative Commons Attribution Non-Commercial No Derivatives (by-ncnd) License $<$ http://creativecommons.org/licenses/by-nc-nd/3.0/>. shown to stimulate the growth of solid tumors in vivo and to promote gastric cancer in the stomach ${ }^{8}$. Tobacco carcinogens can initiate and promote tumorigenesis, so concomitant exposure to nicotine could confer a proliferative advantage to early tumors, although there is no evidence that nicotine itself provokes cancer?.

However, there have only been few reports of in vivo toxicity and histopathological changes on aspiration of nicotine in the respiratory organs. To examine any lung toxicity induced by nicotine, it is necessary to have a system for frequent respiratory exposure. We have previously described a rat in vivo bioassay for detection of hazards due to fine particles by intratracheal instillation (i.t.) ${ }^{10}$, which can be used for risk assessment of inhaled chemicals. The i.t. method has been proposed as the most reliable route for assessing the pulmonary toxicity of particles in rodents ${ }^{11}$, although there are biologically different responses to inhalation and instillation ${ }^{12,13}$. Using this i.t. technique, the present experiment was conducted to histopathologically examine toxicity and cell proliferation caused by nicotine in the lungs by repeated i.t. administration in vivo. 


\section{Materials and Methods}

\section{Chemicals}

Nicotine (chemical formula: $\mathrm{C}_{10} \mathrm{H}_{14} \mathrm{~N}_{2}$ and CAS: 54-115 ) was purchased from Sigma-Aldrich (St. Louis, MO, USA) and suspended in saline (Otsuka isotonic sodium chloride solution, Otsuka Pharmaceutical Factory, Inc., Tokushima, Japan).

\section{Animals}

Male Fischer-344/DuCrlCrj rats (4 weeks of age) purchased from Charles River Laboratories Japan, Inc. (Kanagawa, Japan) were maintained in the Division of Animal Experiments, Life Science Research Center, Kagawa University, according to the Institutional Regulations for Animal Experiments. The regulations included the best considerations for animal welfare and good practice of animal handling contributing to the replacement, refinement and reduction of animal testing (3Rs). The protocols of the experiments were approved by the Animal Care and Use Committee for Kagawa University. The animals were housed in polycarbonate cages with white wood chips for bedding and given free access to drinking water and a basal diet, CE-2 (CLEA Japan, Inc., Tokyo, Japan), under controlled conditions of humidity ( $60 \pm 10 \%)$, lighting (12-h light/dark cycle) and temperature $\left(24 \pm 2^{\circ} \mathrm{C}\right)$. The experiments were started after a 2 -week acclimation period.

\section{Experimental design and tissue preparation}

A total of thirty 6-week-old male F344 rats were randomly separated into 6 groups of 5 rats each and scheduled to be administered nicotine by i.t. ${ }^{10}$ every 3 weeks from week 4 to 28 , for a total of 9 times, and to be sacrificed at week 30 . The doses of nicotine were decided to be $0.05,0.1$ and $0.2 \mathrm{mg}$ nicotine $/ 0.2 \mathrm{ml}$ saline/rat based on the report that $0.2 \mathrm{mg}$ nicotine/rat corresponds to a lethal dose for human adults (30-60 mg, $0.5-1.0 \mathrm{mg} / \mathrm{kg}$ body weight) ${ }^{14,15}$. The $\mathrm{pHs}$ of the diluted nicotine solutions $(0.05,0.1$ and $0.2 \mathrm{mg}$ nicotine $/ 0.2 \mathrm{ml}$ saline) were $9.22,9.42$ and 9.60 , respectively (pH meter F-52, HORIBA, Ltd., Kyoto, Japan). The $\mathrm{pH}$ of the saline used as a vehicle and control was 6.14. During the experiment, the third or fourth administrations were not given to the high-dose group, 0.1 and $0.2 \mathrm{mg}$ nicotine/ rat, because of the death of some rats following nicotine administration. The final experiment protocol was therefore modified as shown in Table 1. The total numbers of admin- istrations and effective numbers of rats were 9 times and 5 rats (Group 3) and 4 times and 5 rats (Group 2) for the 0.05 $\mathrm{mg}$ nicotine/rat group; 3 times and 5 rats (Group 4) and 4 times and 3 rats (Group 5) for the $0.1 \mathrm{mg}$ group; and 3 times and 3 rats (Group 6) for the $0.2 \mathrm{mg}$ group, respectively. As a control group (Group 1), 5 rats were administered $0.2 \mathrm{ml}$ saline/rat 9 times. Total doses of nicotine per rat were 0.00 mg (Group 1), 0.20 (Group 2), 0.45 (Group 3), 0.30 (Group 4), 0.40 (Group 5) and 0.60 (Group 6).

At autopsy, the lungs, liver and kidneys were removed. The lungs were weighed including the trachea and heart first, rinsed in $10 \%$ neutral buffered formalin after excision and then infused with $10 \%$ neutral buffered formalin. The weights of the lungs were calculated by subtraction of the weight of the remaining trachea and heart. The liver and kidneys were weighed and immersed in $10 \%$ neutral buffered formalin for 3 days. Slices of organs were routinely processed for embedding in paraffin for histopathological examination of H\&E-stained sections. For lungs, this was routinely performed for 2 slices of the left lobe and 1 slice each of the other lobes. Each lung lobe was examined histopathologically for neutrophil infiltration, pulmonary edema, pulmonary fibrosis, macrophage infiltration in the alveoli, restructuring of walls, granuloma ${ }^{16}$ and atelectasis. Severity for each parameter, except for atelectasis, was divided as follows: 0 , no change; 1 , weak; 2 , moderate; and 3 , severe. Severity for atelectasis was divided as follows: 0 , none; 1,1 lobe; 2, 2 lobes; and 3, more than 3 lobes.

\section{Statistical analysis}

Body and organ weights were analyzed by the TukeyKramer post hoc test. P values less than 0.05 were considered significant.

\section{Results}

All rats in Groups 4, 5, and 6 ( 0.1 or $0.2 \mathrm{mg}$ nicotine/rat) laid on their backs and suffered convulsions a few seconds after each i.t. administration. This symptom continued for approximately 5 to 10 seconds. At the third or fourth administration, there were a number of mortalities, although other rats survived the acute symptoms. As noted above, due to the deaths, the experimental design was modified, and the number of administrations was modified in some groups.

Final body and organ weights are summarized in Table 2. The body weights of the rats in Group $3(0.05 \mathrm{mg}$ nicotine

Table 1. Details of the Final Experimental Protocol

\begin{tabular}{cccccc}
\hline \multirow{2}{*}{ Groups } & \multirow{2}{*}{ Nicotine/rat (mg) } & \multirow{2}{*}{ Total number of i.t. } & $\begin{array}{c}\text { Total dose of nicotine/ } \\
\text { rat (mg) }\end{array}$ & \multicolumn{2}{c}{ No. of rats } \\
\hline 1 & & & 0.00 & 5 & 5 \\
2 & 0.00 (saline) & 9 & 0.20 & 5 & 5 \\
3 & 0.05 & 9 & 0.45 & 5 & 5 \\
4 & 0.05 & 3 & 0.30 & 5 & 5 \\
5 & 0.10 & 4 & 0.40 & 5 & 3 \\
6 & 0.10 & 3 & 0.60 & 5 & 3 \\
\hline
\end{tabular}


9 times) showed significant decreases compared with Group 1 (control group). Absolute and relative weights of the lung were significantly increased in Groups 2, 3 and 5 compared with Group 1 (control group). Regarding liver weights, there were no significant differences compared with Group 1 (saline control group).

Histopathologically, the lungs of Groups 2-6 (nicotinetreated groups) showed inflammatory changes, neutrophil infiltration, pulmonary edema, pulmonary fibrosis, macrophage infiltration in the alveoli, restructuring of walls and granuloma, in all animals (incidence: 100\%) (Table 3). Atelectasis was observed in Groups 2, 3, 5 and 6. No proliferative alteration of alveolar cells was apparent. The lungs of Group 3 (0.05 mg nicotine 9 times) showed the severest and most widespread inflammatory changes in all rats (Fig. 1-E and F). The inflammation in Groups 2, 4, 5 and 6 persisted until autopsy (week 30), despite the 17-20-week period between the final instillation of nicotine and autopsy. The areas of inflammation in the lungs of Groups 2, 4, 5 and 6 were localized and showed clear borders with normal areas (Fig. 1-C, Fig. 2-A, C, E).

All rats (Group 1-6) also showed severe lymphoid cell infiltration around the bronchus in their lungs with almost the same degree. The saline control group (Group 1) also featured severe lymphoid cell infiltration around the bronchus, but not inflammatory changes in the alveoli (Fig. 1-A, B).

In the kidneys and livers of animals treated with nicotine (Groups 2-6), no remarkable changes were observed macroscopically and histopathologically compared with the control group (Group 1).

\section{Discussion}

In the present study, rats treated with 0.1 or $0.2 \mathrm{mg}$ nicotine suffered convulsions after each i.t. administration. The behavioral effects of nicotine are reported to be attributed to an action on nicotinic receptors, their over stimulation of nicotinic receptors in the brain resulting in clonic-tonic convulsions ${ }^{17}$. Damaj MI et al. reported that nicotine enhances the release of glutamate either directly or indirectly (membrane depolarization that opens L-type calcium channels) and that glutamate release in turn stimulates $\mathrm{N}$-methyl-D-aspartate receptors, thus triggering a cascade of events leading to nitric oxide formation and possibly seizure $^{18}$. Nicotine at a dose of 0.75 or $1.0 \mathrm{mg} / \mathrm{kg}$ body weight is reported to lead to a decrease in cortical after-discharge duration and influence seizure susceptibility, but not cause any detectable neuronal damage ${ }^{19}$.

The body weights of the rats treated nicotine tended to be decreased compared with the control group (Group 1). Furthermore, in Group 3 (0.05 mg nicotine 9 times), the decrease was significant as compared with Group 1 (control group). This decrease in body weight can be considered due to the toxicity of nicotine. The total dose of nicotine in Group 3 was $0.45 \mathrm{mg}$ and was lower than that in Group $6(0.60 \mathrm{mg})$. However, the number of administrations in Group 3 was 9, and this was the maximum number. The results suggest that the decrease in body weight depends not only on the total dose of nicotine in the experiment but also on repeated and consecutive administrations. The lung weights of the rats treated with nicotine were increased significantly compared with the control group (Group 1) but not in the group treated with $0.1 \mathrm{mg}$ nicotine 3 times (Group 4). This result corre-

Table 2. Body and Organ Weights of the Rats

\begin{tabular}{|c|c|c|c|c|c|c|c|c|}
\hline \multirow{2}{*}{ Groups } & \multirow{2}{*}{$\begin{array}{l}\text { Nicotine/ } \\
\text { rat (mg) }\end{array}$} & \multirow{2}{*}{$\begin{array}{l}\text { Total num- } \\
\text { ber of i.t. }\end{array}$} & \multirow{2}{*}{$\begin{array}{l}\text { No. of } \\
\text { rats }\end{array}$} & \multirow{2}{*}{$\begin{array}{l}\text { Body weight } \\
\text { (g) }\end{array}$} & \multicolumn{2}{|c|}{ Liver } & \multicolumn{2}{|c|}{ Lung } \\
\hline & & & & & Absolute (g) & Relative (\%) & Absolute (g) & Relative $(\%)$ \\
\hline 1 & 0.00 (saline) & 9 & 5 & $341.6 \pm 10.6^{\mathrm{a}}$ & $9.7 \pm 0.5$ & $2.8 \pm 0.1$ & $2.0 \pm 0.2$ & $0.6 \pm 0.1$ \\
\hline 2 & 0.05 & 4 & 5 & $314.6 \pm 21.7$ & $8.8 \pm 0.5$ & $2.8 \pm 0.2$ & $2.7 \pm 0.2^{\mathrm{b}, \mathrm{c}}$ & $0.9 \pm 0.1^{\mathrm{b}, \mathrm{c}}$ \\
\hline 3 & 0.05 & 9 & 5 & $304.3 \pm 24.5^{b}$ & $8.9 \pm 0.6$ & $2.9 \pm 0.1$ & $2.8 \pm 0.4^{\mathrm{b}, \mathrm{c}}$ & $0.9 \pm 0.2^{\mathrm{b}, \mathrm{c}}$ \\
\hline 4 & 0.10 & 3 & 5 & $328.9 \pm 13.0$ & $8.6 \pm 0.4$ & $2.6 \pm 0.1$ & $1.6 \pm 0.4$ & $0.5 \pm 0.1$ \\
\hline 5 & 0.10 & 4 & 3 & $335.7 \pm 5.7$ & $9.9 \pm 0.8^{\mathrm{c}}$ & $2.9 \pm 0.3^{\mathrm{c}}$ & $2.9 \pm 0.3^{\mathrm{b}, \mathrm{c}}$ & $0.9 \pm 0.1^{\mathrm{b}, \mathrm{c}}$ \\
\hline 6 & 0.20 & 3 & 3 & $312.1 \pm 7.9$ & $8.8 \pm 0.2$ & $2.8 \pm 0.0$ & $2.6 \pm 0.4^{c}$ & $0.8 \pm 0.1^{\mathrm{c}}$ \\
\hline
\end{tabular}

${ }^{\text {a }}$ Average \pm standard deviation. ${ }^{\mathrm{b}} \mathrm{P}<0.05$ vs. Group $1 .{ }^{\mathrm{c}} \mathrm{P}<0.05$ vs. Group 4.

Table 3. Scoring Indices of Histopathological Changes

\begin{tabular}{|c|c|c|c|c|c|c|c|c|c|c|}
\hline Groups & $\begin{array}{l}\text { Nicotine/ } \\
\text { rat }(\mathrm{mg})\end{array}$ & $\begin{array}{c}\text { Total } \\
\text { number } \\
\text { of i.t. }\end{array}$ & $\begin{array}{l}\text { No. } \\
\text { of } \\
\text { rats }\end{array}$ & $\begin{array}{l}\text { Neutrophil } \\
\text { infiltration }\end{array}$ & $\begin{array}{c}\text { Pulmonary } \\
\text { edema }\end{array}$ & $\begin{array}{c}\text { Pulmonary } \\
\text { fibrosis }\end{array}$ & $\begin{array}{l}\text { Macrophage } \\
\text { infiltration in } \\
\text { the alveoli }\end{array}$ & $\begin{array}{l}\text { Restructur- } \\
\text { ing of the } \\
\text { walls of the } \\
\text { alveoli }\end{array}$ & Granuloma & Atelectasis \\
\hline 1 & 0.00 (saline) & 9 & 5 & $1.0 \pm 0.4^{\mathrm{a}}$ & $0.0 \pm 0.0$ & $0.0 \pm 0.0$ & $1.0 \pm 0.5$ & $0.0 \pm 0.0$ & $1.0 \pm 0.0$ & $0.0 \pm 0.0$ \\
\hline 2 & 0.05 & 4 & 5 & $2.4 \pm 0.5$ & $1.0 \pm 0.0$ & $1.2 \pm 0.4$ & $2.0 \pm 0.0$ & $1.4 \pm 0.5$ & $2.2 \pm 0.5$ & $1.6 \pm 0.9$ \\
\hline 3 & 0.05 & 9 & 5 & $2.8 \pm 0.4$ & $1.6 \pm 0.5$ & $1.4 \pm 0.5$ & $2.2 \pm 0.4$ & $1.4 \pm 0.5$ & $2.8 \pm 0.5$ & $0.6 \pm 0.9$ \\
\hline 4 & 0.10 & 3 & 5 & $2.4 \pm 0.5$ & $1.0 \pm 0.0$ & $1.0 \pm 0.0$ & $1.8 \pm 0.4$ & $1.0 \pm 0.0$ & $2.4 \pm 0.0$ & $0.0 \pm 0.0$ \\
\hline 5 & 0.10 & 4 & 3 & $2.7 \pm 0.6$ & $1.7 \pm 0.6$ & $1.3 \pm 0.6$ & $1.7 \pm 0.6$ & $1.7 \pm 0.6$ & $2.7 \pm 0.6$ & $2.3 \pm 0.6$ \\
\hline 6 & 0.20 & 3 & 3 & $2.3 \pm 1.2$ & $1.3 \pm 0.6$ & $1.3 \pm 0.6$ & $1.7 \pm 0.6$ & $1.3 \pm 0.6$ & $2.0 \pm 0.6$ & $2.0 \pm 1.0$ \\
\hline
\end{tabular}

${ }^{\text {a }}$ Average \pm standard deviation. 

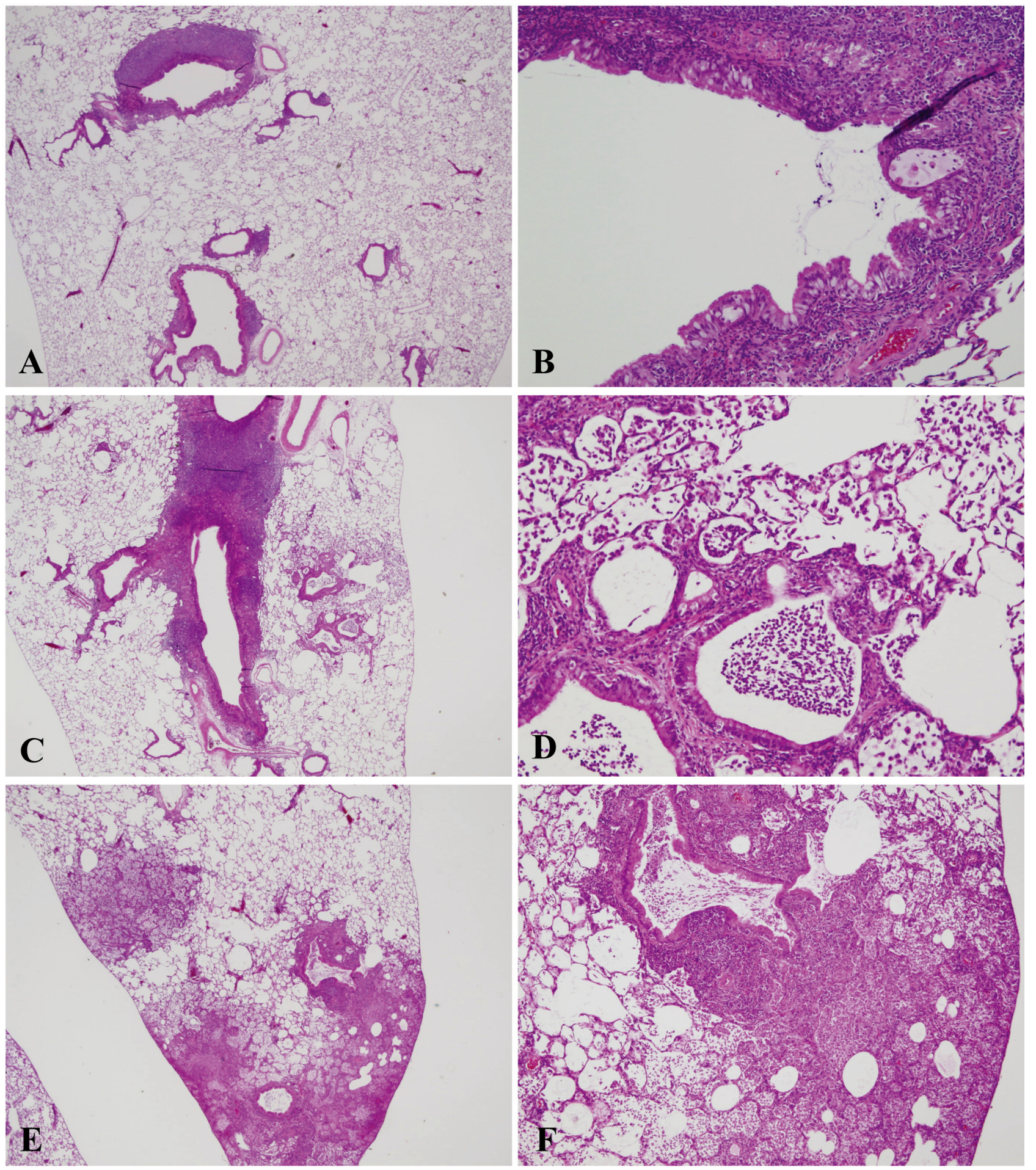

Fig. 1. Histopathological findings for lungs in Groups 1-3. The lungs of Group 3 ( $0.05 \mathrm{mg}$ nicotine 9 times) showed the severest inflammatory changes in all rats (E and F). Inflammation in Group 2 ( $0.05 \mathrm{mg} 4$ times) persisted until autopsy (week 30). The saline control group (Group 1) also demonstrated severe lymphoid cell infiltration around the bronchus, as in the other groups (Group 2-6) (A and B). A, saline control $\times 9$ (Group 1) (magnification: $\times 20)$; B, saline control $\times 9$ (Group 1) $(\times 200) ; \mathrm{C}, 0.05 \mathrm{mg}$ nicotine $\times 4$ (group 2$)$ $(\times 12.5)$; D, $0.05 \mathrm{mg}$ nicotine $\times 4$ (group 2) $(\times 100)$; E, $0.05 \mathrm{mg}$ nicotine $\times 9$ (group 3) $(\times 12.5) ; \mathrm{F}, 0.05 \mathrm{mg}$ nicotine $\times 9$ (group 3) $(\times 40)$.

sponds with inflammatory change caused by nicotine in the lungs, excluding the decrease in lung weight in Group 4.

Histopathologically, the lungs of Group $3(0.05 \mathrm{mg}$ nicotine 9 times, $0.45 \mathrm{mg}$ total dose) showed the severest and most widespread inflammatory changes in all rats. Histopathological inflammation also did not solely depend on the total dose of nicotine in the experiment, and repeated and consecutive administrations correspond with a de- 

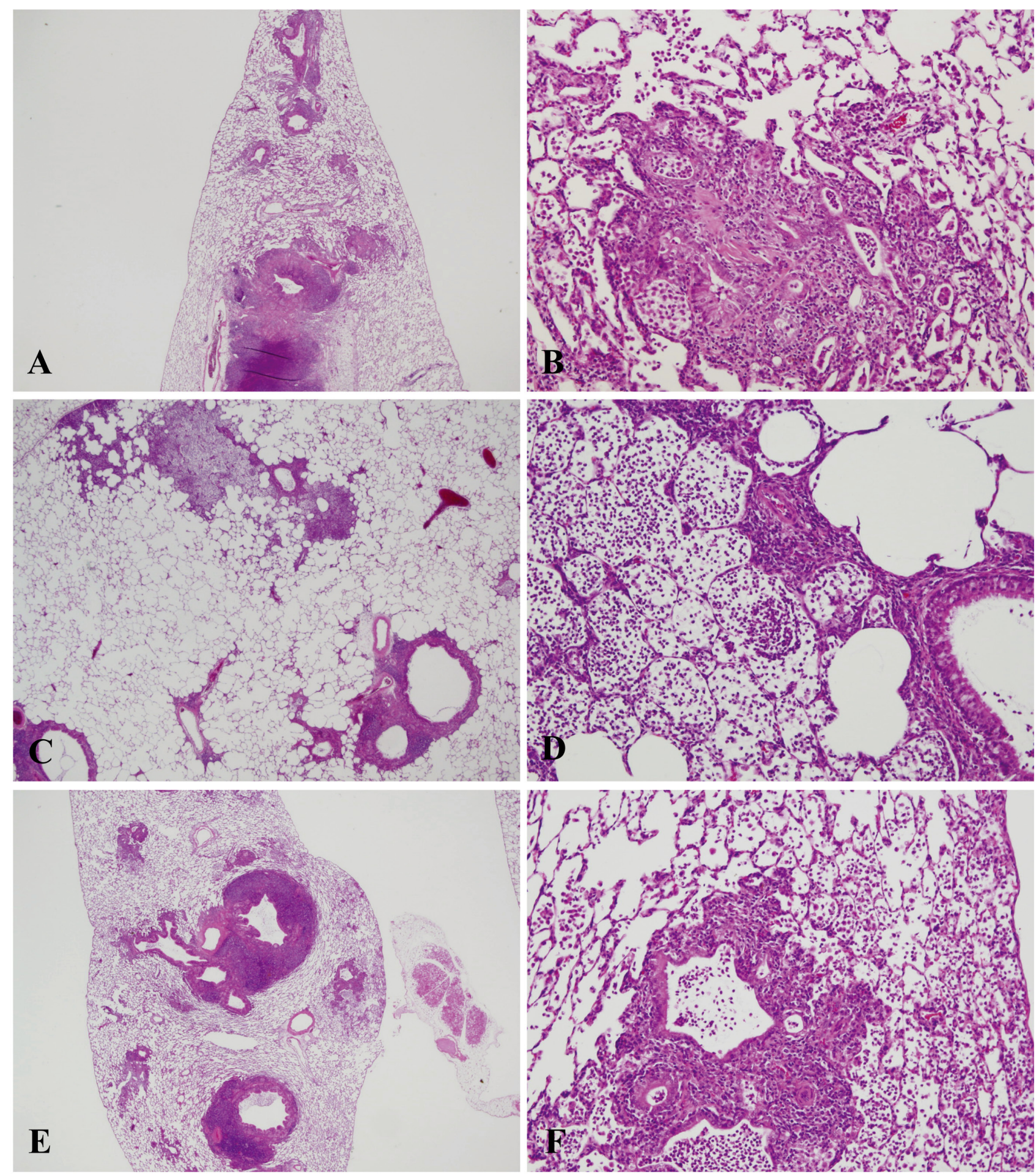

Fig. 2. Histopathological findings for lungs in Groups 4-6. Inflammation in Groups 4, 5 and 6 persisted until autopsy (week 30) with severe lymphoid cell infiltration around the bronchus (A-F). A, $0.10 \mathrm{mg}$ nicotine $\times 3$ (Group 4) (magnification: $\times 12.5$ ); $\mathrm{B}, 0.10 \mathrm{mg}$ nicotine $\times 3($ Group 4$)(\times 100) ; \mathrm{C}, 0.10 \mathrm{mg}$ nicotine $\times 4$ (Group 5) $(\times 20) ; \mathrm{D}, 0.10 \mathrm{mg}$ nicotine $\times 4$ (Group 5) $(\times 100) ; \mathrm{E}, 0.20 \mathrm{mg}$ nicotine $\times 3$ (Group 6) $(\times 12.5)$; F, $0.20 \mathrm{mg}$ nicotine $\times 3$ (group 6$)(\times 100)$.

crease in body weight. Mabley $\mathrm{J}$ et al. reported that intraperitoneal injection of 0.2 or $0.4 \mathrm{mg} / \mathrm{kg}$ nicotine exerts an anti-inflammatory effect in a murine model of acute lung injury induced by intratracheal lipopolysaccharide (LPS, 50 $\mu \mathrm{l})^{20}$. The difference in the result of their report, exerting an anti-inflammation effect, and our experiment, inducing an inflammatory change, is suggested to be due to the difference in administration route. In the present experiment, the 
$\mathrm{pHs}$ of the diluted nicotine solutions $(0.05,0.1$ and $0.2 \mathrm{mg}$ nicotine $/ 0.2 \mathrm{ml}$ saline) were very alkaline at 9.22, 9.42 and 9.60, respectively (saline: 6.14). Alkaline compounds cause liquefaction necrosis, which in turn causes ongoing invasion into deeper layers of tissue ${ }^{21}$. This is the same problem that occurs with accidental drinking of lye solution, the high $\mathrm{pH}$ of which is associated with esophageal ulceration. Vancula EM et al. concluded that the critical $\mathrm{pH}$ that causes esophageal ulceration is $12.5^{21}$. This is much higher than the solutions used in the present experiment. However, because the target organ is different, it is difficult to conclude that lung inflammatory changes were due to the nicotine itself or the high $\mathrm{pH}$.

All rats (Groups 1-6) showed almost the same degree of severe lymphoid cell infiltration around the bronchus in their lungs, not only those treated with nicotine but also those treated with saline vehicle alone. Our previous 30 -week experiment using F344 male rats also showed severe lymphoid cell infiltration around the trachea in a saline control group with $100 \%$ incidence, and this finding was reported as large granular lymphocytic lymphoma (LGL lymphoma) $)^{22}$. In this context, it should be mentioned that F344 rats demonstrate an incidence of over $50 \%$ of LGL lymphoma in aged animals ${ }^{23}$. Frith $\mathrm{CH}$ et al. concluded that lymphoid cell neoplasms in F344 rat should not be grouped with nonlymphoid neoplasms in determining the toxicity and carcinogenicity of test substances ${ }^{24}$.

CYP2A5 is reported to be involved in metabolism of nicotine and its major circulating metabolite, cotinine, in the mouse liver ${ }^{25}$. CYP2A5, a mouse cytochrome P450 monooxygenase that shows high similarities to human CYP2A6 and CYP2A13 in protein sequence and substrate specificity, is expressed in multiple tissues, including the liver, kidney, lung and nasal mucosa. In humans, CYP2A6 is the predominant enzyme responsible for $70-80 \%$ of nicotine metabolism to cotinine ${ }^{26,27}$. The much higher exposure to cotinine than to nicotine in smokers should be taken into consideration, since cotinine suppression of apoptosis may play an important role in lung tumorigenesis in vivo ${ }^{28}$. We have established a bioassay using the tobacco-specific nitrosamine, 4-(methylnitrosamino)-1-(3-pyridyl)-1-butanone (NNK) as an initiating carcinogen ${ }^{29}$. In the lungs of $\mathrm{A} / \mathrm{J}$ female mice, the initial event in this model is reported to be formation of $\mathrm{O}^{6}$-methylguanine-DNA, a major promutagenic adduct that leads to $\mathrm{GC}>\mathrm{AT}$ transitional mispairing and subsequent activation of the K-ras proto-oncogene ${ }^{30,31}$. We have previously reported inhibitory effects of 8-methoxypsoralen, a potent human CYP2A6 inhibitor, on NNK-induced lung carcinogenesis in female $\mathrm{A} / \mathrm{J}$ mice ${ }^{32,33}$. Human CYP2A6 (mouse CYP2A5) might affect the metabolism of both nicotine and NNK. Therefore, it is strongly expected that human CYP2A6 inhibitors would have major effects on lung carcinogenesis after administration of nicotine and NNK.

In conclusion, repeated i.t. treatment with nicotine in the present study was associated with neurologic symptoms (convulsions) in the acute phase, and marked inflammation in the lungs in the chronic phase, even at a low dose. Toxic- ity of nicotine is suggested to depend not on total dose of nicotine in the experiment but rather repeated and consecutive exposure.

Acknowledgments: We thank Dr. Malcolm A. Moore for critical reading of the manuscript and Sanae Kushida for assistance in its preparation.

\section{References}

1. Smith CJ, and Hansch C. The relative toxicity of compounds in mainstream cigarette smoke condensate. Food Chem Toxicol. 38: 637-646. 2000. [Medline] [CrossRef]

2. Hone AJ, Meyer EL, McIntyre M, and McIntosh JM. Nicotinic acetylcholine receptors in dorsal root ganglion neurons include the alpha6beta4* subtype. FASEB J. 26: 917 926. 2012. [Medline] [CrossRef]

3. Catanzaro DF, Zhou Y, Chen R, Yu F, Catanzaro SE, De Lorenzo MS, Subbaramaiah K, Zhou XK, Pratico D, Dannenberg AJ, and Weksler BB. Potentially reduced exposure cigarettes accelerate atherosclerosis: evidence for the role of nicotine. Cardiovasc Toxicol. 7: 192-201. 2007. [Medline] [CrossRef]

4. Alamanda V, Singh S, Lawrence NJ, and Chellappan SP. Nicotine-mediated induction of E-selectin in aortic endothelial cells requires Src kinase and E2F1 transcriptional activity. Biochem Biophys Res Commun. 418: 56-61. 2012. [Medline] [CrossRef]

5. Özkan KU, Ozokutan BH, Inanc F, Boran C, and Kilinc M. Does maternal nicotine exposure during gestation increase the injury severity of small intestine in the newborn rats subjected to experimental necrotizing enterocolitis. J Pediatr Surg. 40: 484-488. 2005. [Medline] [CrossRef]

6. Khalil AA, Jameson MJ, Broaddus WC, Lin PS, and Chung TD. Nicotine enhances proliferation, migration, and radioresistance of human malignant glioma cells through EGFR activation. Brain Tumor Pathol. 2012.

7. Cardinale A, Nastrucci C, Cesario A, and Russo P. Nicotine: specific role in angiogenesis, proliferation and apoptosis. Crit Rev Toxicol. 42: 68-89. 2012. [Medline] [CrossRef]

8. Liu Y, and Liu BA. Enhanced proliferation, invasion, and epithelial-mesenchymal transition of nicotine-promoted gastric cancer by periostin. World J Gastroenterol. 17: 2674-2680. 2011. [Medline] [CrossRef]

9. Grozio A, Catassi A, Cavalieri Z, Paleari L, Cesario A, and Russo P. Nicotine, lung and cancer. Anticancer Agents Med Chem. 7: 461-466. 2007. [Medline] [CrossRef]

10. Yokohira M, Takeuchi H, Yamakawa K, Saoo K, Ikeda M, Matsuda Y, Zeng Y, Hosokawa K, Maeta H, and Imaida K. Establishment of a bioassay system for detection of lung toxicity due to fine particle instillation: Sequential histopathological changes with acute and subacute lung damage due to intratracheal instillation of quartz in F344 male rats. J Toxicol Pathol. 18: 13-18. 2005. [CrossRef]

11. Warheit DB, Brock WJ, Lee KP, Webb TR, and Reed KL. Comparative pulmonary toxicity inhalation and instillation studies with different $\mathrm{TiO} 2$ particle formulations: impact of surface treatments on particle toxicity. Toxicol Sci. 88: 514-524. 2005. [Medline] [CrossRef] 
12. Osier M, and Oberdorster G. Intratracheal inhalation vs intratracheal instillation: differences in particle effects. Fundam Appl Toxicol. 40: 220-227. 1997. [Medline] [CrossRef]

13. Yokohira M, Kuno T, Yamakawa K, Hashimoto N, Ninomiya F, Suzuki S, Saoo K, and Imaida K. An intratracheal instillation bioassay system for detection of lung toxicity due to fine particles in F344 rats. J Toxicol Pathol. 22: 1-10. 2009. [Medline] [CrossRef]

14. Gosselin R, Smith R, Hodge H, and Braddock J. Clinical Toxicology of Commercial Products. Williams \& Wilkins, Baltimore. 311-313. 1988.

15. Okamoto M, Kita T, Okuda H, Tanaka T, and Nakashima T. Effects of aging on acute toxicity of nicotine in rats. Pharmacol Toxicol. 75: 1-6. 1994. [Medline] [CrossRef]

16. Yokohira M, Kuno T, Yamakawa K, Hosokawa K, Matsuda Y, Hashimoto N, Suzuki S, Saoo K, and Imaida K. Lung toxicity of 16 fine particles on intratracheal instillation in a bioassay model using f344 male rats. Toxicol Pathol. 36: 620-631. 2008. [Medline] [CrossRef]

17. Czuczwar M, Kis J, Czuczwar P, Wielosz M, and Turski W. Nicotine diminishes anticonvulsant activity of antiepileptic drugs in mice. Pol J Pharmacol. 55: 799-802. 2003. [Medline]

18. Damaj MI, Glassco W, Dukat M, and Martin BR. Pharmacological characterization of nicotine-induced seizures in mice. J Pharmacol Exp Ther. 291: 1284-1291. 1999. [Medline]

19. Riljak V, Maresova D, and Pokorny J. Nicotine effects on rat seizures susceptibility and hippocampal neuronal degeneration. Neuro Endocrinol Lett. 31: 792-795. 2010. [Medline]

20. Mabley J, Gordon S, and Pacher P. Nicotine exerts an antiinflammatory effect in a murine model of acute lung injury. Inflammation. 34: 231-237. 2011. [Medline] [CrossRef]

21. Vancura EM, Clinton JE, Ruiz E, and Krenzelok EP. Toxicity of alkaline solutions. Ann Emerg Med. 9: 118-122. 1980. [Medline] [CrossRef]

22. Yokohira M, Hashimoto N, Yamakawa K, Suzuki S, Saoo $\mathrm{K}$, Kuno T, and Imaida K. Lung carcinogenic bioassay of $\mathrm{CuO}$ and $\mathrm{TiO}(2)$ nanoparticles with intratracheal instillation using F344 male rats. J Toxicol Pathol. 22: 71-78. 2009. [Medline] [CrossRef]

23. Stromberg PC, and Vogtsberger LM. Pathology of the mononuclear cell leukemia of Fischer rats. I. Morphologic studies. Vet Pathol. 20: 698-708. 1983. [Medline] [CrossRef]

24. Frith $\mathrm{CH}$, Ward JM, and Chandra M. The morphology, immunohistochemistry, and incidence of hematopoietic neoplasms in mice and rats. Toxicol Pathol. 21: 206-218. 1993. [Medline] [CrossRef]
25. Zhou X, Zhuo X, Xie F, Kluetzman K, Shu YZ, Humphreys WG, and Ding X. Role of CYP2A5 in the clearance of nicotine and cotinine: insights from studies on a Cyp2a5-null mouse model. J Pharmacol Exp Ther. 332: 578-587. 2010. [Medline] [CrossRef]

26. Nakajima M, Yamamoto T, Nunoya K, Yokoi T, Nagashima $\mathrm{K}$, Inoue K, Funae Y, Shimada N, Kamataki T, and $\mathrm{Ku}-$ roiwa Y. Role of human cytochrome P4502A6 in C-oxidation of nicotine. Drug Metab Dispos. 24: 1212-1217. 1996. [Medline]

27. Nakajima M, Yamamoto T, Nunoya K, Yokoi T, Nagashima K, Inoue K, Funae Y, Shimada N, Kamataki T, and Kuroiwa Y. Characterization of CYP2A6 involved in 3'-hydroxylation of cotinine in human liver microsomes. J Pharmacol Exp Ther. 277: 1010-1015. 1996. [Medline]

28. Nakada T, Kiyotani K, Iwano S, Uno T, Yokohira M, Yamakawa K, Fujieda M, Saito T, Yamazaki H, Imaida K, and Kamataki T. Lung tumorigenesis promoted by anti-apoptotic effects of cotinine, a nicotine metabolite through activation of PI3K/Akt pathway. J Toxicol Sci. 37: 555-563. 2012. [Medline] [CrossRef]

29. Yokohira M, Takeuchi H, Saoo K, Matsuda Y, Yamakawa K, Hosokawa K, Kuno T, and Imaida K. Establishment of a bioassay model for lung cancer chemoprevention initiated with 4-(methylnitrosamino)-1-(3-pyridyl)-1-butanone (NNK) in female A/J mice. Exp Toxicol Pathol. 60: 469473. 2008. [Medline] [CrossRef]

30. Peterson LA, and Hecht SS. O6-methylguanine is a critical determinant of 4-(methylnitrosamino)-1-(3-pyridyl)-1-butanone tumorigenesis in A/J mouse lung. Cancer Res. 51: 5557-5564. 1991. [Medline]

31. Ronai ZA, Gradia S, Peterson LA, and Hecht SS. G to A transitions and $\mathrm{G}$ to $\mathrm{T}$ transversions in codon 12 of the $\mathrm{Ki}$ ras oncogene isolated from mouse lung tumors induced by 4-(methylnitrosamino)-1-(3-pyridyl)-1-butanone (NNK) and related DNA methylating and pyridyloxobutylating agents. Carcinogenesis. 14: 2419-2422. 1993. [Medline] [CrossRef]

32. Takeuchi H, Saoo K, Yokohira M, Ikeda M, Maeta H, Miyazaki M, Yamazaki H, Kamataki T, and Imaida K. Pretreatment with 8-methoxypsoralen, a potent human CYP2A6 inhibitor, strongly inhibits lung tumorigenesis induced by 4-(methylnitrosamino)-1-(3-pyridyl)-1-butanone in female A/J mice. Cancer Res. 63: 7581-7583. 2003. [Medline]

33. Takeuchi H, Saoo K, Matsuda Y, Yokohira M, Yamakawa K, Zeng Y, Miyazaki M, Fujieda M, Kamataki T, and Imaida K. Dose dependent inhibitory effects of dietary 8-methoxypsoralen on NNK-induced lung tumorigenesis in female A/J mice. Cancer Lett. 234: 232-238. 2006. [Medline] [CrossRef] 